\title{
Sequential confocal microscopy of corneal nerve regeneration in myopia surgery by PRK
}

\section{Microscopía confocal secuencial de regeneración nerviosa corneal en operado de miopía por PRK}

\author{
Eduardo Rojas-Alvarez ${ }^{1 *}$ and Janet González-Sotero² \\ ${ }^{1}$ Universidad de Cuenca, Cuenca; ${ }^{2}$ Universidad Católica de Santiago de Guayaquil, Guayaquil. Ecuador
}

Different moments of regeneration of the stromal nerves and sub-basal nerve plexus are observed in images taken at the same depth with the microscope Confoscan $4^{\circledR}$ (NIDEK). The stromal nerves are located in the anterior and middle stroma; they appear as linear, thin, reflective structures in different orientations, with a dichotomous pattern. No internal details of the nerves are observed ${ }^{1}$. In the sequence, the increase in reflectivity and nerve length during the first postoperative year is observed. The sub-basal nerves are located between the Bowman's membrane and the basal epithelium. They appear as linear structures with homogeneous reflectivity, a dichotomous appearance with a $\mathrm{Y}$ shape, and fine interconnection fibers with an $\mathrm{H}$ shape $^{1}$. The absence of lamellar cut influences that after PRK the preoperative characteristics of the sub-basal nerve plexus recover more quickly, and this recovery is complete one year after the surgery. The depth of ablation, the amount of stromal tissue removed and the depth of damage to the stromal nerves are closely related ${ }^{2}$ figure 1.

\section{Ethical responsibilities}

Protection of human and animal subjects. The authors declare that no experiments were performed on humans or animals for this study.
Confidentiality of data. The authors declare that they have followed the protocols of their work center on the publication of patient data.

Right to privacy and informed consent. The authors have obtained the written informed consent of the patients or subjects mentioned in the article. The corresponding author is in possession of this document.

\section{Funding}

The authors received no specific funding for this work.

\section{Conflict of interest}

The authors declare no conflicts of interest.

\section{References}

1. Rojas Álvarez E, González Sotero J, Tamargo Barbeito TO. Mode-los predictivos de morfometría corneal a partir de la ametropía atratar con láser excímer. Arch Soc Esp Oftalmol. 2015;90:312-23.

2. Rojas Álvarez E, González Sotero J. LASIK vs. LASEK desde lapers pec- tiva morfométrica corneal in vivo. Rev Mex Oftalmol.2013; 87:145-57.
Available online: 14-05-2018 Rev Mex Oftalmol(Eng).2018;92(3):143-144 www.rmo.com.mx 2604-1731/O 2016 Sociedad Mexicana de Oftalmología. Published by Permanyer México SA de CV. This is an Open Access article under the CC BY-NC-ND license (http://creativecommons.org/licenses/by-nc-nd/4.0/). 
Rev Mex Oftalmol (Eng). 2018;92

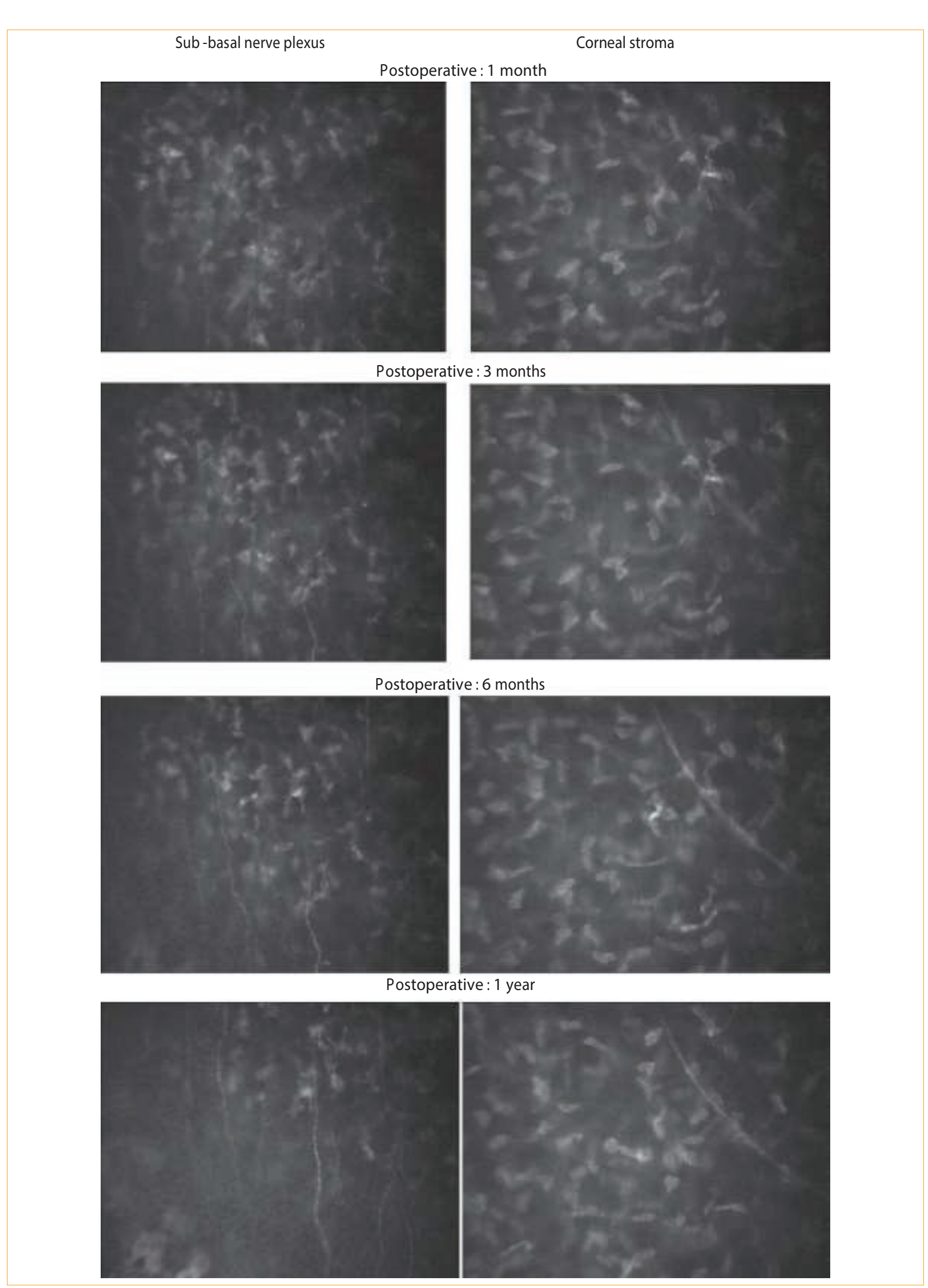

Figure 1. Confocal microscopy sequential images. Patient with PRK history at different postoperative time points: 1 month, 3 months, 6 months, 1 year. Right: corneal stroma; left: sub-basal nerve plexus. 